\title{
MAKNA RUANG PUBLIK PADA RUMAH TRADISIONAL MASYARAKAT JAWA KASUS STUDI: DESA JAGALAN KOTAGEDE YOGYAKARTA
}

\author{
Sumardiyanto ${ }^{1}$, Antariksa $^{2}$, Purnama Salura ${ }^{3}$ \\ ${ }^{1}$ Program Studi Arsitektur Universitas Atma Jaya Yogyakarta \\ 2Jurusan Arsitektur Universitas Brawijaya \\ ${ }^{3}$ Jurusan Arsitektur Universitas Katolik Parahyangan \\ mr.antariksa@gmail.com, purnamasalura@yahoo.com
}

\begin{abstract}
ABSTRAK. Penelitian ini bertujuan untuk mengungkap pemahaman tentang ruang publik pada rumah tinggal masyarakat Jawa. Untuk itu dipilih rumah-rumah tradisional masyarakat Jawa tipe joglo di desa Jagalan Kotagede Yogyakarta sebagai representasi aspek bentuk. Untuk representasi aspek fungsi dipilih tiga adat dan upacara daur hidup yaitu kelahiran, perkawinan dan kematian. Pendekatan dasar yang digunakan adalah strukturalisme yang dikembangkan oleh Levi Strauss dikombinasikan dengan pengkategorisasian aspek dalam arsitektur oleh Capon dan perputaran aspek fungsi - bentuk - makna oleh Salura dan Fauzy. Langkah yang dilakukan dalam penelitian ini adalah mengungkap struktur permukaan aspek fungsi dengan menelusuri elemen-elemen dan relasi sintagmatik dari kegiatan pada adat dan upacara kelahiran, perkawinan dan kematian. Pada saat yang sama juga dilakukan pengungkapan struktur permukaan aspek bentuk melalui penelusuran elemen-elemen dan relasi sintagmatik dari rumah-rumah kasus studi. Langkah berikutnya adalah melakukan analisis oposisi biner untuk mendapatkan relasi paradigmatik antara struktur permukaan aspek fungsi dan struktur permukaan aspek bentuk. Hasilnya kemudian diinterpretasi lebih lanjut dengan mengkaitkannya dengan konsepkonsep yang hidup dalam masyarakat. Hasil analisis menunjukkan bahwa ruang publik pada rumah tinggal masyarakat Jawa merupakan bagian integral masyarakat Jawa dalam rangka menemukan keselamatan dalam hidup.
\end{abstract}

Kata Kunci : ruang publik, makna, rumah tradisional, Kotagede.

ABSTRACT. This research is aimed to explore the understanding of public space within Javanese traditional house. For this reason, it has been chosen some Javanese traditional houses known as Joglo House as case studies. Those houses are located in Jagalan Village, Kotagede Yogyakarta which will represent as form aspect. To represent function aspect, it has been conducted three ritual life cycle ceremonies consist birth, marriage and death. The basic approach that has been used is structuralism which has been developed by Levi Strauss and has been combined with aspect categorization in architecture by Capon as well as rotation aspect of function-form-meaning by Salura and Fauzy. Steps taken in this research is describing the surface structure of function aspect by exploring elements and sintagmatic relation from the activities of ritual ceremony of birth, marriage and death. In the same time, it will describe the surface structure of form aspect through exploring elements and sintagmatic relation of case studies conducted. Next step is by doing binary opposition analysis to get paradigmatic relation between surface structure of function aspect and form aspect. The result will be interpretated more by relating with the concept of living within community. Analysis result has shown that public space on Javanese traditional house is an integral part of Javanese community in a term to find a safety life.

Key Words : public space, meaning, traditional house, Kotagede

\section{PENDAHULUAN}

Ruang publik merupakan cerminan nilai publik dan nilai privat yang tumbuh dalam suatu masyarakat [1]. Pembagian ruang menjadi area publik dan privat merupakan salah satu kunci dalam prinsip pengorganisasian dan pembentukan ruang fisik kota [2]. Pembedaan antara rumah (mewakili area privat) dan jalan (mewakili area publik) seperti yang ditemukan pada kota-kota modern saat ini juga telah ditemukan dalam kota Ur di Mesopotamia lebih dari empat ribu tahun yang lalu. Hal ini mengindikasikan adanya keterkaitan antara pembedaan ruang publik dan privat dengan cara manusia menjalin hubungan satu dengan yang lain.

Di era global yang ditandai dengan kemajuan tekonologi informasi, konsep dan gagasan tentang ruang publik yang telah berkembang dan diterapkan secara luas dalam perancangan ruang kehidupan di kalangan masyarakat Barat (Amerika dan Eropa) mengalir deras ke negara-negara lain. Konsep ruang publik Barat tersebut kemudian diadopsi dan diwujudkan di negara-negara lain tanpa 
memperhatikan kesesuaiannya dengan nilainilai budaya lokal.

Globalisasi yang di satu sisi mendorong kesadaran seseorang menjadi bagian dari masyarakat global, di sisi lain menumbuhkan pula dorongan untuk lebih melestarikan dan memperkuat identitas nasionalnya. Gejala ini dikenal dengan istilah global paradox [3]. Dalam konteks inilah maka penggalian konsep ruang publik lokal menjadi penting untuk dilakukan.

Masyarakat Jawa sebagai salah satu suku bangsa terbesar di Indonesia, tersebar hampir di seluruh wilayah Indonesia. Akibatnya hampir di semua provinsi di Indonesia selalu dapat ditemui komunitas masyarakat Jawa beserta tradisi-tradisi dan nilai-nilai lokal yang mereka bawa dari tanah Jawa. Oleh karena itu sangatlah strategis mengungkap pemahaman ruang publik pada rumah tradisional masyarakat Jawa.

Penelitian ini menggunakan pendekatan strukturalisme yang dikembangkan oleh LeviStrauss [4] dikombinasikan dengan pendekatan pengkategorisasian aspek dalam arsitektur oleh Capon [5] dan teori perputaran aspek fungsi - bentuk - makna oleh Salura dan Fauzy [6]. Pendekatan ini belum pernah dilakukan pada penelitian-penelitian sebelumnya sehingga hasilnya memberi pandangan baru terhadap ruang publik yang berlandaskan nilai-nilai lokal dan memberikan alternatif cara membaca sebuah karya arsitektur.

Kegunaan dan manfaat dari penelitian ini pertama memberi pemahaman baru terhadap ruang publik, kedua memberi alternatif cara membaca karya arsitektur, ketiga memberi masukan kepada seluruh pemangku kepentingan yang terkait dengan perancangan ruang publik, dan akhirnya mengangkat ruang publik yang berlandaskan nilai-nilai lokal dalam percakapan internasional.

\section{KASUS STUDI DAN METODE}

\section{Kasus studi}

Lokasi penelitian ini adalah desa Jagalan Kotagede yang terletak sekitar 6 kilometer sebelah Tenggara kota Yogyakarta. Kotagede adalah kawasan pusaka yang sejak tahun 1577 menjadi ibukota kerajaan Mataram Islam sebelum akhirnya pada tahun 1618 ibukota dipindah ke Kerta oleh Sultan Agung yang memerintah Mataram saat itu [7]. Sampai saat ini di Kotagede masih dapat dijumpai rumahrumah tradisional yang berada dalam keadaan terawat dengan baik.

Untuk mewakili aspek bentuk, dipilih rumah tradisional masyarakat Jawa tipe joglo sebagai kasus studi. Untuk mewakili keberagaman status sosial ekonomi masyarakat maka dipilih tiga buah rumah dengan susunan ruang yang bervariasi. Rumah kasus studi pertama adalah milik ibu Nurjohan yang susunan ruangnya masih sangat lengkap (dalem, pendhapa, gandhok kiwa, gandhok tengen, pawon dan pekiwan). Rumah kasus studi kedua adalah rumah milik ibu Trisyani yang susunan ruangnya kurang lengkap (dalem, pendhapa, gandhok kiwa dan pawon) dan rumah kasus studi ketiga adalah rumah milik bapak Suwarsono yang susunan ruangnya minimal (dalem, gandhok kiwa dan pawon).

Untuk mewakili aspek fungsi, dipilih adat dan upacara daur hidup, yaitu adat dan upacara kelahiran, perkawinan dan kematian. Ketiga adat dan upacara daur hidup tersebut dipilih karena masyarakat Kotagede merupakan masyarakat tradisional yang masih sangat ketat menjalankan tradisi yang diwariskan oleh para leluhurnya.

\section{Metode}

Metode penelitian yang digunakan merupakan gabungan antara pendekatan strukturalisme yang dikembangkan oleh Levi-Strauss, pengkategorisasian aspek dalam arsitektur oleh Capon dan perputaran fungsi - bentuk makna oleh Salura dan Fauzy. Penggabungan ketiga pendekatan tersebut menghasilkan langkah-langkah sebagai berikut:

a. Pengungkapan struktur permukaan aspek fungsi. Pada langkah ini dilakukan identifikasi terhadap elemen-elemen dari tiga adat dan upacara daur hidup (kelahiran, perkawinan dan kematian). Selanjutnya dicari relasi sintagmatik antar elemen untuk menghasilkan struktur permukaan aspek fungsi.

b. Pengungkapan struktur permukaan aspek bentuk. Pada langkah ini dilakukan identifikasi terhadap elemen-elemen dari rumah tradisional tipe joglo. Selanjutnya dicari relasi sintagmatik antar elemen untuk menghasilkan struktur permukaan aspek bentuk.

c. Pengungkapan struktur dalam. Pada langkah ini dilakukan analisa oposisi biner dan pencarian relasi paradigmatik antara struktur permukaan aspek fungsi dan struktur permukaan aspek bentuk sehingga ditemukan struktur dalam. 
d. Interpretasi. Pada langkah terakhir ini dilakukan interpretasi terhadap struktur dalam dengan cara mengkaitkannya dengan konsep-konsep yang hidup dalam masyarakat Jawa.
Secara diagramatis langkah-langkah penelitian ini dapat disampaikan dalam diagram berikut ini.

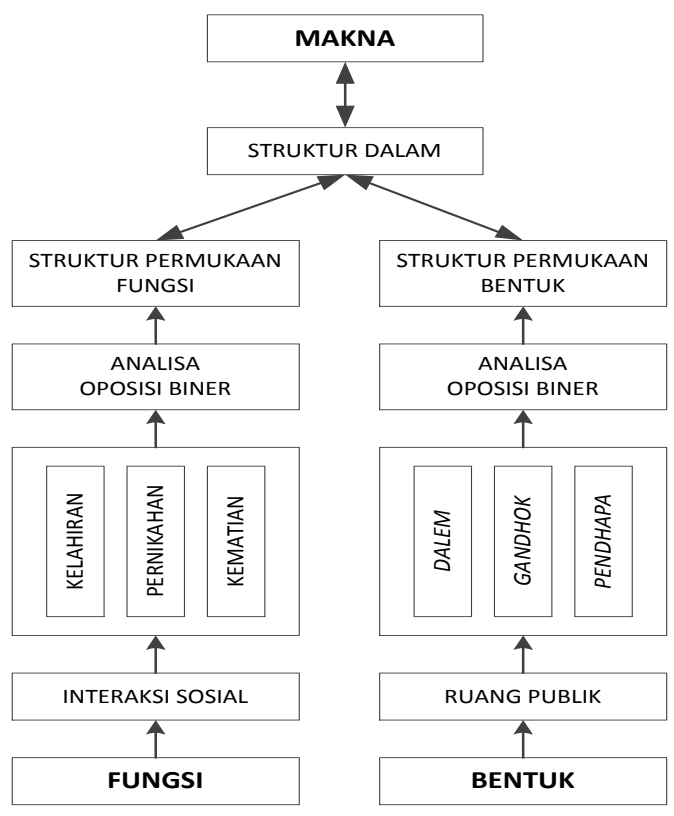

Gambar 1. Diagram Langkah-langkah pengungkapan relasi fungsi - bentuk - makna.

\section{ANALISA}

\section{Pengungkapan Struktur Permukaan Aspek Fungsi}

Langkah awal yang dilakukan adalah identifikasi pelaksanaan adat dan upacara daur hidup pada rumah kasus studi. Langkah berikutnya adalah mengidentifikasi elemenelemen dari adat dan upacara daur hidup yang terdiri dari: pertamadoa/ mantera dan sesaji bagi arwah para leluhur, kedua doa/ mantera dan sesaji bagi benda-benda yang dianggap memiliki kekuatan gaib, dan ketiga makan bersama/ kenduri/ bancakan.

Ketiga elemen adat dan upacara daur hidup tersebut dapat dikelompokkan menjadi dua berdasarkan sifat fisik dari aktivitas, yaitu pertama aktivitas yang bersifat nirfisik (doa/ mantera) dan kedua aktivitas yang bersifat fisik (kenduril bancakan). Uraian tersebut dapat dijelaskan dengan skema sebagai berikut.

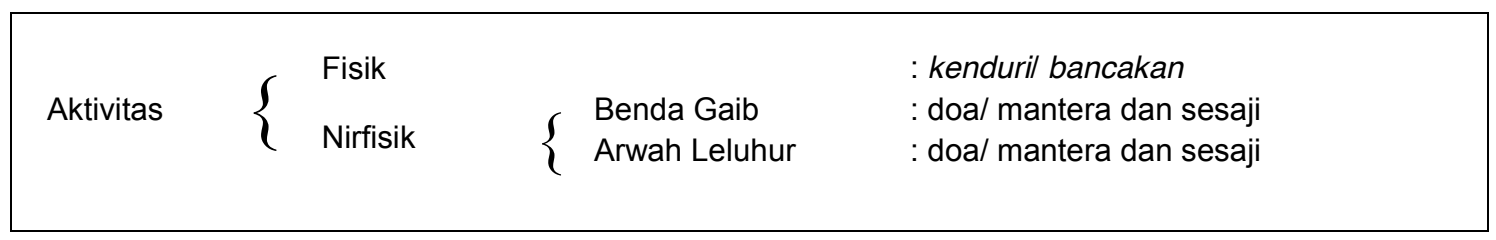

Gambar 2. Diagram Pembagian Aktivitas

Ketiga elemen tersebut selanjutnya dapat dijelaskan dengan relasi oposisi biner. Selain relasi oposisi biner yang ditentukan oleh sifat fisik aktivitas, relasi oposisi biner juga dapat dilihat berdasarkan penghormatan, ketaatan pelaksanaan dan sifat fisik sumber keselamatan pada upacara dan selamatan daur hidup.

Dari pelaksanaan adat dan upacara daur hidup pada semua kasus studi terungkap bahwa terdapat variasi dalam hal penghormatan dan 
ketaatan menjalankan adat dan upacara. Penghormatan terhadap arwah dan benda melalui doa/ mantera dan sesaji sifatnya mutlak sedangkan penghormatan terhadap masyarakat melalui kenduril bancakan bersifat relatif. Hal ini terjadi karena status sosial seseorang dalam masyarakat sifatnya relatif dan sangat dinamis sehingga pelaksanaannya sangat ditentukan oleh status sosial seseorang dalam masyarakat.

Hal yang sama terjadi pada ketaatan terhadap pelaksanaan adat dan upacara daur hidup. Dari seluruh kasus studi ditemukan bahwa ketaatan terhadap arwah dan benda gaib melalui doa/ mantera dan sesaji sangat tinggi dan sebaliknya ketaatan terhadap masyarakat melalui kenduril bancakan sifatnya rendah. Hal ini terjadi karena status sosial seseorang bersifat relatif dan dinamis. Hal yang berbeda adalah pada sifat fisik sumber keselamatan. Pada doa/ mantera dan sesaji bagi arwah leluhur sifat fisik dari sumber keselamatan adalah arwah yang bersifat nirfisik, sedangkan pada doa/ mantera dan sesaji bagi benda gaib serta kenduril bancakan sifat fisik sumber keselamatannya adalah fisik berupa benda gaib dan masyarakat.

Relasi tersebut dapat dirangkum dalam tabel berikut.

Tabel 1. Relasi antar Elemen Adat dan Upacara Daur Hidup

\begin{tabular}{|c|c|c|c|c|c|}
\hline & & & Elemen & at dan Upacara & idup \\
\hline & Relasi & Karakter & $\begin{array}{l}\text { Doa/ Mantera } \\
\text { dan Sesaji bagi } \\
\text { Arwah Leluhur }\end{array}$ & $\begin{array}{c}\text { Doa/ Mantera } \\
\text { dan Sesaji bagi } \\
\text { Benda Gaib }\end{array}$ & $\begin{array}{c}\text { Kenduril } \\
\text { bancakan }\end{array}$ \\
\hline 1 & Sifat fisik aktivitas & Nirfisik & ya & ya & tidak \\
\hline 1 & sıtat tisık aktıvitas & Fisik & tidak & tidak & ya \\
\hline 2 & Sifat fisik sumber & Nirfisik & ya & tidak & tidak \\
\hline 2 & keselamatan & Fisik & tidak & ya & ya \\
\hline 3 & Penghormatan & Mutlak & ya & ya & tidak \\
\hline 0 & rengnumalan & Relatif & tidak & tidak & ya \\
\hline 4 & Ketaatan & $\begin{array}{l}\text { Tinggi } \\
\text { Rendah }\end{array}$ & ya & ya & tidak \\
\hline & & Rendah & tidak & tidak & ya \\
\hline
\end{tabular}

Uraian tentang relasi dan oposisi biner tersebut dapat digunakan untuk mengungkap struktur di balik pelaksanaan upacara dan selamatan daur hidup (kelahiran, perkawinan dan kematian) yang dilaksanakan pada rumah kasus studi. Pertama, upacara dan selamatan merupakan upaya untuk mendapatkan keselamatan berupa aktivitas yang bersifat fisik dan nirfisik. Kedua, aktivitas yang bersifat fisik berupa kenduril bancakan dan aktivitas yang bersifat nirfisik terdiri atas doa/ mantera dan sesaji bagi arwah leluhur dan doa/ mantera dan sesaji bagi benda gaib. Oposisi biner yang ada pada aktivitas selametan tersebut dapat dilihat pada gambar 3. Kedua kutub yang saling beroposisi ini selanjutnya dapat digabungkan dan digambarkan menjadi satu model. Penggabungan dua oposisi biner tersebut merupakan struktur dari sumber keselamatan pada upacara dan selamatan daur hidup (kelahiran, perkawinan dan kematian) (gambar 4).

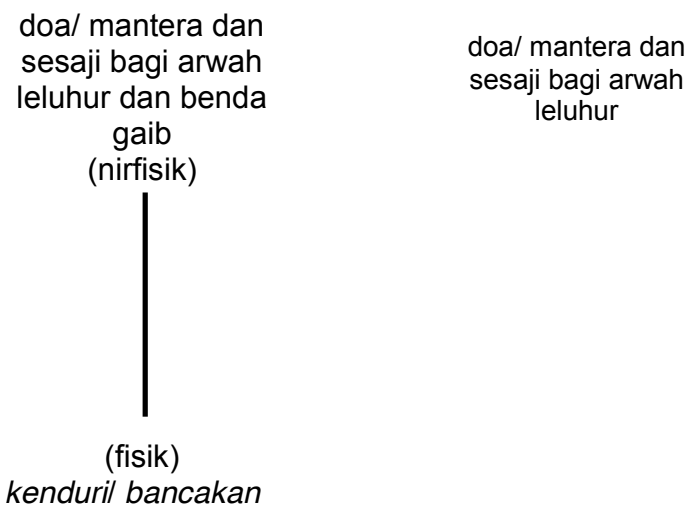

kenduril bancakan

Gambar 3. Oposisi Biner pada Aktivitas Selametan 
doa/ mantera dan sesaji bagi arwah leluhur

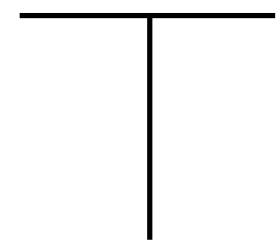

doa/ mantera dan sesaji

bagi benda gaib

kenduril bancakan

Gambar 4. Penggabungan dua Oposisi Biner

Antara doa/ mantera dan sesaji bagi arwah dan bagi benda gaib terdapat kesamaan dan perbedaan. Kesamaan terletak pada penghormatan dan ketaatan masyarakat terhadap kedua doa/ mantera dan sesaji tersebut yang bersifat mutlak. Perbedaan di antara kedua doa/ mantera dan sesaji terletak pada sifatnya, arwah bersifat nirfisik sementara benda gaib dan masyarakat bersifat fisik. Antara doa/ mantera dan sesaji bagi benda gaib dan kenduril bancakan juga terdapat kesamaan dan perbedaan. Kesamaan antara doa/ mantera dan sesaji bagi benda gaib dan kenduri/ bancakan bagi masyarakat adalah sama-sama obyeknya bersifat fisik. Perbedaan di antara keduanya terletak pada penghormatan dan ketaatan masyarakat. Penghormatan dan ketaatan masyarakat terhadap doa/ mantera dan sesaji bagi benda gaib bersifat mutlak, sedangkan penghormatan dan ketaatan masyarakat terhadap kenduri/ bancakan bagi masyarakat bersifat relatif. Antara doa/ mantera dan sesaji bagi arwah leluhur dengan kenduril bancakan bagi masyarakat tidak ada kesamaan. Terkait dengan upacara dan selamatan yang dilakukan dalam upacara daur hidup, model tersebut dapat dikembangkan lebih lanjut menjadi gambaran struktur yang ada di balik adat dan upacara daur hidup di lingkungan masyarakat Jawa.

\section{Pengungkapan Struktur Permukaan aspek Bentuk}

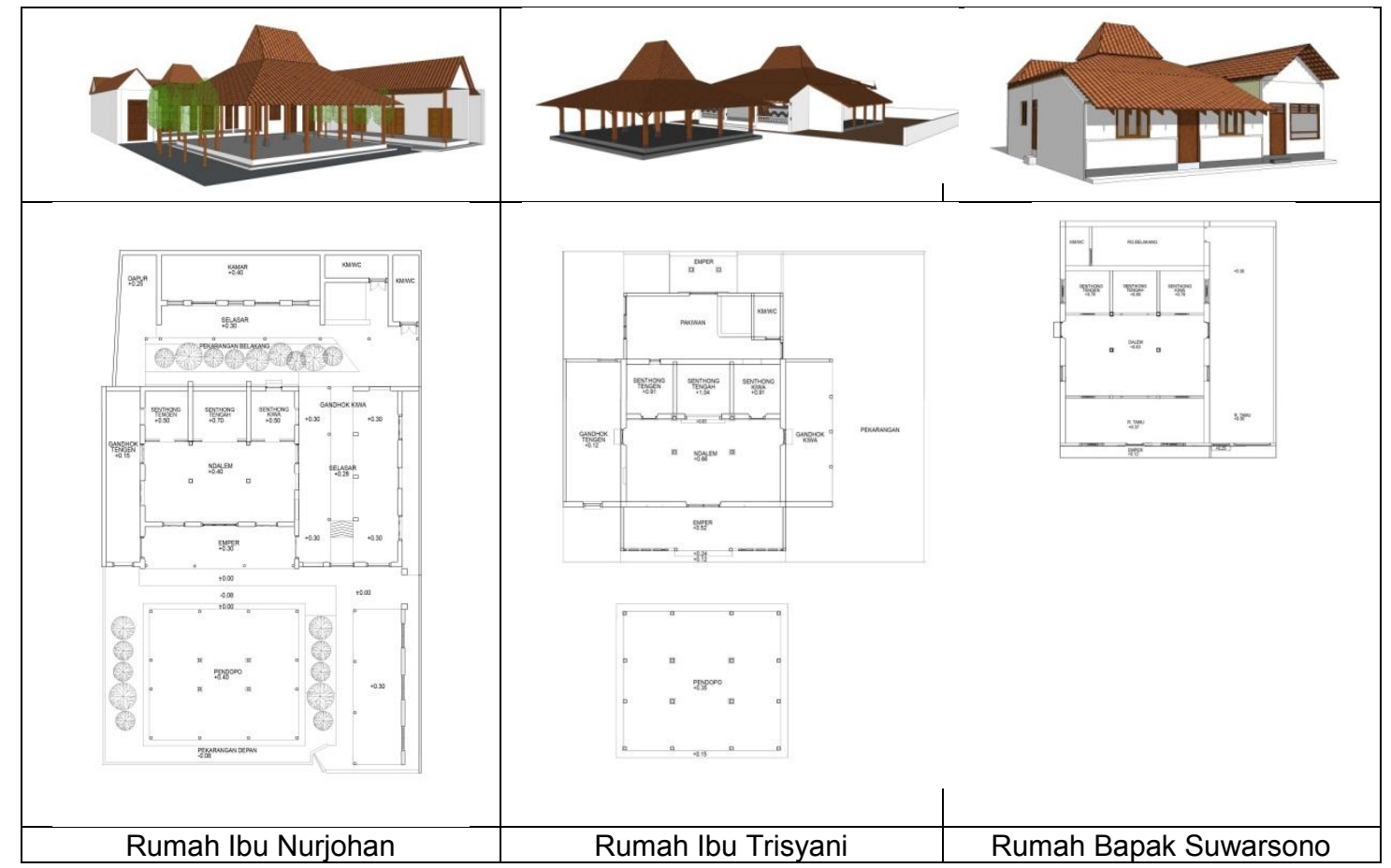

Gambar 5. Rumah Kasus Studi

Dari ketiga rumah studi kasus tersebut kemudian dipilih ruang yang terdapat pada pada ketiganya, yaitu dalem untuk dianalisa lebih lanjut. Dalam bangunan dalem terdiri dari 
berbagai elemen yang dapat dimasukkan dalam berbagai kategori. Kategorisasi dapat dilakukan secara vertikal maupun secara horisontal. Kemudian dari masing-masing kategorisasi dapat ditemukan elemen-elemen yang lebih kecil.

\section{Elemen-elemen berdasarkan kategorisasi Vertikal}

Dalam kategorisasi vertikal terhadap bangunan secara keseluruhan dapat ditemukan elemenelemen bagian bawah, bagian tengah dan bagian atas. Bagian bawah adalah lantai (jogan), bagian tengah adalah tiang (sakal cagak) dan bagian atas terdiri dari atap (empyak). Pada masing-masing elemen (lantai, tiang dan atap) dapat dirinci lagi sehingga ditemukan elemen-elemen yang lebih kecil.

Tiap-tiap elemen pada masing-masing kategori memiliki kaitan satu terhadap yang lain. Elemen lantai terdiri dari lantai emper, lantai dalem dan lantai senthong. Elemen tiang terdiri dari saka guru, saka penanggap, saka emper. Pada bangunan dalem dengan bentuk atap joglo saka guru adalah tiang yang menopang atap brunjung (atap bagian pusat yang menjulang ke atas). Saka penanggap adalah saka yang ada di luar saka guru, fungsinya untuk menopang atap penanggap yang mengelilingi atap brunjung. Saka emper adalah saka di luar saka penanggap yang berfungsi menopang atap emper yang mengelilingi atap penanggap. Pada ketiga kasus studi saka bagian paling luar berupa tembok atau dinding batu bata. Identifikasi terhadap ketinggian lantai emper, dalem dan senthong (dalam hal ini adalah senthong tengah) menunjukkan bahwa pada semua kasus studi semakin ke belakang terjadi peningkatan ketinggian lantai.

Apabila kategorisasi vertikal dan horisontal digabung, akan terlihat bahwa emper, saka emper serta atap emper ada dalam kategori bawah - depan. Dalem ada dalam kategori tengah baik secara vertikal maupun horisontal. Senthong ada dalam kategori atas - belakang. Saka guru serta atap brunjung berada pada kategori tengah - atas. Saka penanggap serta atap penanggap ada dalam kategori tengah belakang.Penggabungan kategori tersebut menunjukkan adanya dua orientasi utama dalam bangunan dalem. Apabila dilihat dari tata ruang, maka orientasi utama terlihat pada senthong yang ada dalam kategori atas belakang. Jika dilihat dari atap maka orientasi lain terlihat pada atap brunjung dan atap limas (didukung oleh saka guru) yang ada pada kategori atas - tengah.

Penggabungan kedua kategorisasi tersebut menghasilkan tiga elemen yang saling beroposisi yang dapat dikelompokkan menjadi dua berdasarkan posisi kategorisasinya, yaitu pertama elemen yang berada pada posisi tengah/ belakang - atas dan kedua elemen yang berada pada posisi depan - bawah. Uraian tersebut dapat dijelaskan dengan gambar 6 di bawah ini.

$$
\begin{array}{|l}
\text { Elemen }\left\{\begin{array} { l l | } 
{ \text { Depan - Bawah } } \\
{ \text { Tengah/ Belakang - Atas } }
\end{array} \left\{\begin{array}{ll}
\text { Tengah - Atas } & \text { : emper } \\
\text { Belakang - Atas } & \text { brunjung } \\
\text { : senthong }
\end{array}\right.\right. \\
\hline
\end{array}
$$

Gambar 6. Diagram pembagian elemen

Ketiga elemen tersebut selanjutnya dapat dijelaskan dengan relasi oposisi biner. Selain relasi oposisi biner yang ditentukan oleh posisi secara vertikal dan horisontal, relasi oposisi biner juga dapat dilihat berdasarkan ketaatan masyarakat terhadap ketentuan posisi vertikal dan horisontal.Melalui pengamatan terhadap keberadaan elemen-elemen fisik pada semua kasus studi terungkap bahwa terdapat variasi dalam hal ketaatan melaksanakan pembangunan berdasarkan prinsip vertikal dan horisontal. Ketaatan terhadap pembangunan atap utama (brunjung) dan senthong sifatnya mutlak sedangkan ketaatan terhadap keberadaan emper dan pengembangannya bersifat relatif. Hal ini terjadi karena kebutuhan pengembangan emper terkait dengan status sosial seseorang dalam masyarakat yang sifatnya relatif dan sangat dinamis sehingga pelaksanaannya sangat ditentukan oleh status sosial seseorang dalam masyarakat. Relasi tersebut dapat dirangkum dalam tabel 2 berikut. 
Tabel 2. Relasi antar Elemen Fisik Bangunan Dalem

\begin{tabular}{lllccc}
\hline & & & \multicolumn{3}{c}{ Elemen Fisik Bangunan Dalem } \\
\hline \multirow{2}{*}{ Relasi } & Karakter & Senthong & \multicolumn{2}{c}{$\begin{array}{c}\text { Atap } \\
\text { brunjung\&sakaguru }\end{array}$} & $\begin{array}{c}\text { Emper/saka } \\
\text { emper }\end{array}$ \\
\hline \multirow{2}{*}{1} & $\begin{array}{l}\text { Kategorisasi } \\
\text { Vertikal }\end{array}$ & Atas & ya & ya & Tidak \\
\cline { 2 - 6 } & Bawah & tidak & tidak & Ya \\
\hline \multirow{2}{*}{2} & $\begin{array}{l}\text { Kategorisasi } \\
\text { Horisontal }\end{array}$ & Belakang & ya & tidak & Tidak \\
\cline { 2 - 6 } & Depan & tidak & ya & Ya \\
\hline 4 & Ketaatan & Tinggi & ya & ya & Tidak \\
\hline & & Rendah & tidak & tidak & Ya \\
\hline
\end{tabular}

Uraian tentang relasi dan oposisi biner tersebut dapat digunakan untuk mengungkap struktur di balik pembangunan elemen-elemen fisik yang dilaksanakan pada rumah kasus studi.Pertama, elemen-elemen fisik bangunan terdiri dari elemen fisik yang berada di depan bawah dan tengah/ belakang - atas. Kedua, elemen fisik yang berada pada posisi depan bawah berupa emper - saka emper dan elemen fisik yang berada pada posisi tengah/ belakang - atas terdiri atas saka guru - atap brunjung dan senthong.

Oposisi biner yang ada pada elemen fisik tersebut dapat dilihat pada gambar 7 . Kedua kutub yang saling beroposisi ini selanjutnya dapat digabungkan dan digambarkan menjadi satu model. Penggabungan dua oposisi biner tersebut merupakan struktur dari relasi antar elemen-elemen fisik pada bangunan dalem. (gambar 8)

Antara senthong dan saka guru - atap brunjung/ limas terdapat kesamaan dan perbedaan. Kesamaan terletak pada ketaatan masyarakat terhadap kedua elemen tersebut yang bersifat mutlak. Perbedaan di antara kedua elemen terletak pada orientasinya, orientasi atas dari lantai senthong bersifat simbolis sementara orientasi atas bagi saka guru - atap brunjungl limas bersifat fisik (langit). Antara saka guru - atap brunjungl limas dan emper - saka panitih juga terdapat kesamaan dan perbedaan.

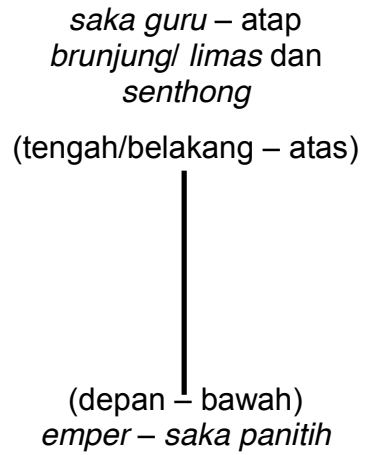

Gambar 7. Oposisi Biner pada elemen Fisik

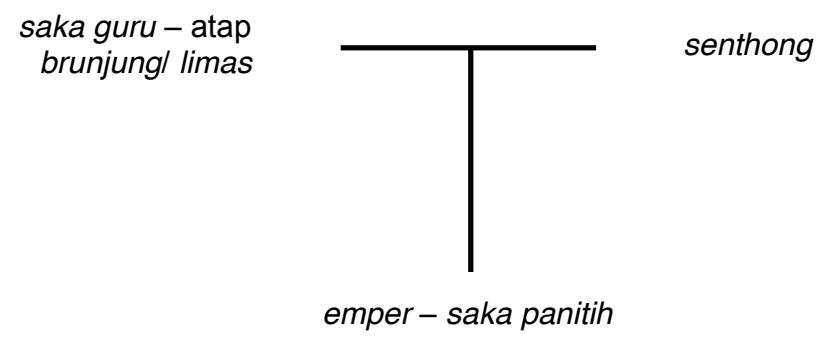

Gambar 8. Penggabungan Dua Oposisi Biner

Kesamaan antara saka guru - atap brunjungl limas dan emper - saka panitih adalah sama- sama obyek orientasinya bersifat fisik yaitu langit dan tanah. Perbedaan di antara 
keduanya terletak pada ketaatan masyarakat. Ketaatan masyarakat terhadap keberadaan saka guru - atap brunjungl limas bersifat mutlak, sedangkan ketaatan masyarakat terhadap emper dan pengembangannya bersifat relatif. Antara senthong dengan emper tidak ada kesamaan. Terkait dengan elemen fisik pada bangunan dalem, model tersebut dapat dikembangkan lebih lanjut menjadi gambaran struktur yang ada di balik bangunan rumah tradisional di lingkungan masyarakat Jawa.

\section{Pengungkapan struktur dalam}

Rumah sebagai tempat perlindungan bagi keluarga haruslah merupakan tempat yang dapat memberikan keselamatan. Oleh karena itu ruang-ruang yang ada pada sebuah rumah juga harus selaras dengan lingkungan yang dipercaya ada dalam kehidupan masyarakat Jawa. Lingkungan tersebut terdiri dari lingkungan adikodrati, lingkungan alam dan lingkungan masyarakat [8]. Lingkunganlingkungan tersebut dapat dikelompokkan menjadi dua berdasarkan sifat fisiknya dan selanjutnya dapat disusun sebuah relasi. Relasi tersebut dapat digambarkan sebagai berikut.

Lingkungan $\left\{\begin{array}{ll|}\text { Adikodrati } \\ \text { "Kodrati" }\end{array} \begin{cases}\text { Alam } & : \text { dunia arwah } \\ \text { Masyarakat } & : \text { alam semesta } \\ & \text { : tetangga }\end{cases}\right.$

Gambar 9. Diagram pembagian lingkungan

Ketiga lingkungan tersebut selanjutnya dapat dijelaskan dengan relasi oposisi biner. Selain relasi oposisi biner yang berkaitan dengan sifat fisik lingkungan ("kodrati" dan adikodrati) ada juga oposisi biner berdasarkan penghormatan dan ketaatan masyarakat terhadap lingkunganlingkungan tersebut. Lingkungan adikodrati sifatnya tidak terlihat sedangkan lingkungan "kodrati" yang terdiri dari lingkungan alam dan masyarakat sifatnya terlihat. Penghormatan masyarakat terhadap lingkungan adikodrati dan lingkungan alam sifatnya mutlak, sedangkan penghormatan terhadap lingkungan masyarakat bersifat relatif. Hal ini terjadi karena status sosial dalam masyarakat bersifat relatif dan dinamis. Berdasarkan alasan yang sama, ketaatan masyarakat terhadap lingkungan adikodrati dan lingkungan alam tinggi sedangkan ketaatan terhadap lingkungan masyarakat rendah. Keseluruhan unsur dan elemen yang beroposisi biner tersebut dapat dirangkum dalam tabel berikut.

Tabel 3. Relasi Unsur-unsur Lingkungan

\begin{tabular}{|c|c|c|c|c|c|}
\hline & & & \multicolumn{3}{|c|}{ Lingkungan } \\
\hline & Relasi & Karakter & Adikodrati & Alam & Masyarakat \\
\hline \multirow[t]{2}{*}{1} & Sifat fisik & Tidak Terlihat & ya & Tidak & tidak \\
\hline & & Terlihat & tidak & $\mathrm{Ya}$ & ya \\
\hline \multirow[t]{2}{*}{2} & Penghormatan & Mutlak & ya & $\mathrm{Ya}$ & tidak \\
\hline & & Relatif & tidak & Tidak & ya \\
\hline \multirow[t]{2}{*}{3} & Ketaatan & Tinggi & ya & $\mathrm{Ya}$ & tidak \\
\hline & & Rendah & tidak & Tidak & ya \\
\hline
\end{tabular}

Oposisi biner yang ada pada lingkungan tersebut dapat digambarkan sebagai berikut.

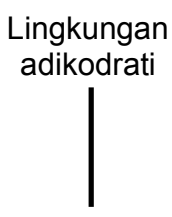

lingkungan "kodrati”
Lingkungan alam
Lingkungan

masyarakat

Gambar 10. Oposisi Biner pada Lingkungan 
Kedua kutub yang saling beroposisi ini selanjutnya dapat digabungkan dan digambarkan menjadi satu model.Penggabungan dua oposisi biner tersebut merupakan struktur dari lingkungan yang harus dijaga keselarasannya pada perwujudan ruang-ruang yang ada pada rumah tradisional masyarakat Jawa. (gambar 11)

Lingkungan

adikodrati

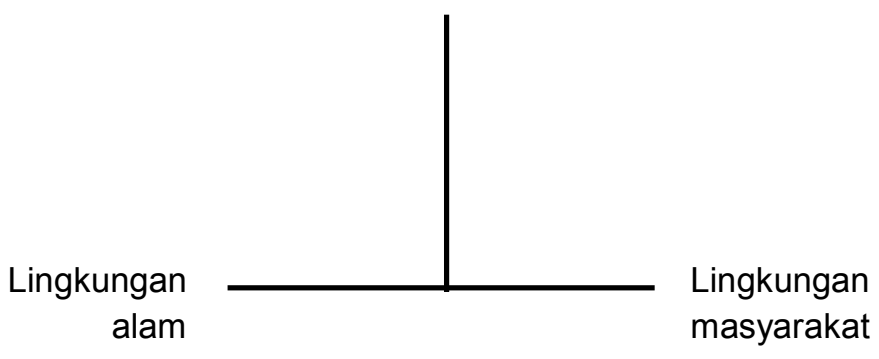

Gambar 11. Penggabungan Dua Oposisi Biner

Antara lingkungan adikodrati dengan lingkungan alam terdapat kesamaan dan perbedaan. Kesamaan ada pada penghormatan dan ketaatan terhadap kedua lingkungan tersebut. Perbedaannya terletak pada karakter fisiknya, lingkungan adikodrati bersifat nirfisik sedangkan lingkungan alam bersifat fisik.Antara lingkungan alam dengan lingkungan masyarakat juga memiliki kesamaan dan perbedaan. Kesamaan antara lingkungan alam dengan lingkungan masyarakat terletak pada sifatnya yang samasama fisik. Perbedaan antara lingkungan alam dan lingkungan masyarakat terletak penghormatan dan ketaatan masyarakat. Ketaatan masyarakat terhadap lingkungan alam bersifat mutlak, sedangkan ketaatan masyarakat terhadap lingkungan masyarakat bersifat relatif. Antara lingkungan adikodrati dan lingkungan masyarakat tidak ada kesamaan.

Berdasarkan hasil pengungkapan struktur permukaan aspek fungsi dan struktur permukaan aspek bentuk, maka dapat dilihat adanya transformasi fenomena sosial budaya pada rumah tradisional masyarakat Jawa. Struktur permukaan tersebut dapat diothakathik sedemikian rupa sehingga dapat ditempatkan berbagai struktur lahir dalam sebuah untaian struktur yang memperlihatkan transformasi-transformasi atau alih rupa yang dialami oleh struktur tersebut [9].

Fenomena yang terlihat pada aspek fungsi yaitu pelaksanaan adat dan upacara kelahiran, perkawinan dan kematian adalah doa/ mantera dan sesaji untuk arwah leluhur, doa/ mantera dan sesaji untuk benda-benda dengan kekuatan gaib, dan kenduril bancakan. Fenomena yang terlihat pada aspek bentuk seperti terlihat pada dalem adalah senthong (terdiri dari senthong tengah, senthong kiwa dan senthong tengen), relasi bangunan dengan alam semesta, dan jogan/ amben. Berbagai fenomena budaya dengan struktur tersebut telah memperlihatkan adanya transformasi secara empiris.Proses transformasi tersebut dapat dibaca lewat tabel berikut ini.

Tabel 4. Transformasi Fenomena Budaya

\begin{tabular}{|c|c|c|c|}
\hline \multirow{2}{*}{$\begin{array}{l}\text { Fenomena Budaya } \\
\text { Adat dan Upacara } \\
\text { Kelahiran, Perkawinan dan } \\
\text { perkawinan } \\
\text { Dalem }\end{array}$} & \multicolumn{3}{|c|}{ Unsur-unsur } \\
\hline & $\begin{array}{l}\text { Doa/ mantera dan } \\
\text { sesaji untuk arwah } \\
\text { leluhur }\end{array}$ & $\begin{array}{l}\text { Doa/ mantera dan sesaji } \\
\text { untuk benda-benda } \\
\text { dengan kekuatan gaib }\end{array}$ & kenduril bancakan \\
\hline & $\begin{array}{l}\text { Senthong tengah, } \\
\text { senthong kiwa dan } \\
\text { senthong tengen }\end{array}$ & $\begin{array}{l}\text { Saka guru - atap } \\
\text { brunjung }\end{array}$ & $\begin{array}{l}\text { Emper-saka } \\
\text { emper }\end{array}$ \\
\hline
\end{tabular}


Dari tabel tersebut di atas terlihat adanya keterulangan (regularities) dalam dua fenomena budaya yang diamati yaitu adat dan upacara kelahiran, perkawinan dan kematian; dan wujud dari dalem dari sebuah rumah. Lebih jelasnya dapat dikatakan bahwa unsurunsur adat dan upacara daur hidup yang terdiri dari doa/ mantera dan sesaji untuk arwah leluhur, doa/ mantera dan sesaji untuk bendabenda dengan kekuatan gaib dan kenduril bancakan berkonfigurasi ke struktur dari perwujudan ruang dalem yang terdiri dari senthong (terdiri dari senthong tengah, senthong kiwa dan senthong tengen), saka guru - atap brunjung, dan emper - saka emper.

Hubungan antara fenomena budaya satu dengan fenomena budaya yang lain, dalam hal ini mewakili aspek fungsi dan aspek bentuk merupakan hubungan transformasi logis. Artinya, hubungan tersebut tidak terdapat dalam tataran empiris, melainkan ada pada tataran logika atau pemikiran.Struktur yang telah terungkap dalam relasi sintagmatik dapat pula dibaca dalam relasi paradigmatik sehingga menunjukkan secara lebih nyata adanya transformasi atau alih rupa.

\begin{tabular}{|c|c|c|c|}
\hline $\begin{array}{l}\text { Fenomena } \\
\text { Budaya }\end{array}$ & & Unsur-unsur & \\
\hline $\begin{array}{l}\text { Adat dan Upacara } \\
\text { Kelahiran, } \\
\text { Perkawinan } \\
\text { dan Kematian }\end{array}$ & $\begin{array}{c}\text { Doa/ mantera dan } \\
\text { sesaji } \\
\text { untuk arwah leluhur }\end{array}$ & $\begin{array}{c}\text { Doa/ mantera } \\
\text { dan sesaji untuk benda } \\
\text { dengan kekuatan gaib }\end{array}$ & $\begin{array}{c}\text { kenduril } \\
\text { bancakan }\end{array}$ \\
\hline Dalem & $\begin{array}{l}\text { Senthong tengah, } \\
\text { senthong kiwa dan } \\
\text { senthong tengen }\end{array}$ & $\begin{array}{c}\text { Saka guru - atap } \\
\text { brunjung/ limas }\end{array}$ & $\begin{array}{c}\text { Emper-saka } \\
\text { panitih }\end{array}$ \\
\hline
\end{tabular}

Gambar 12. Diagram relasi sintagmatik dan paradigmatik

Berdasarkan gambar di atas, seluruh rangkaian fenomena budaya bersama-sama dengan unsur-unsurnya dapat dibaca secara sintagmatik (mendatar) dan kemudian dibandingkan secara paradigmatik (vertikal) sehingga dapat dibaca bahwa doa/ mantera dan sesaji untuk arwah leluhur dibanding dengan doa/ mantera dan sesaji untuk bendabenda dengan kekuatan gaib, dibanding dengan kenduril bancakan adalah sama seperti senthong (senthong tengah, senthong kiwa dan senthong tengen) dibanding saka guru - atap brunjung, dibanding emper. Hal ini menunjukkan bahwa persamaan antar fenomena budaya bukanlah terletak pada isi melainkan pada relasi antar fenomena, namun pada tataran yang berbeda. Hal ini juga menegaskan bahwa dalam analisa struktural isi sudah tidak ada lagi karena isi ditentukan oleh relasi. Jadi, yang ada adalah relasi atau dengan kata lain, isi adalah relasi itu sendiri.

Apabila struktur yang muncul sebagai fenomena budaya empiris dikaitkan dengan lingkungan yang diyakini ada dalam hidup masyarakat Jawa, yaitu lingkungan masyarakat, lingkungan alam dan lingkungan adikodrati, maka elemen-elemen yang terdapat pada upacara daurhidup maupun ruang-ruang pada dalem memiliki kesesuaian secara struktural.

Doa/ mantera, dan sesaji bagi arwah leluhur serta senthong (senthong tengah, senthong kiwa dan senthong tengen) berada pada posisi di antara lingkungan adikodrati dan lingkungan masyarakat. Doa/ mantera, dan sesaji bagi benda-benda yang memiliki kekuatan gaib serta saka guru - atap brunjung berada di antara lingkungan adikodrati dan lingkungan alam. Kenduril bancakan serta emper berada pada posisi di antara lingkungan alam dan lingkungan masyarakat. Keterulangan struktur permukaan aspek fungsi dan aspek bentuk tersebut menunjukkan adanya struktur yang tetap dan tidak berubah yaitu struktur dalam itu sendiri. Ruang publik yang merupakan wadah interaksi sosial tercermin dalam kegiatan kenduri/ bancakan berlangsung di emper. 


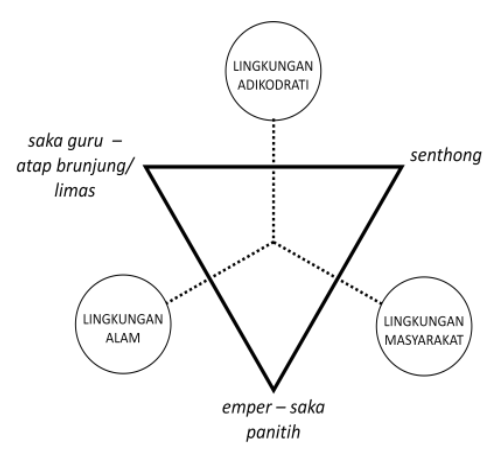

Gambar 13. Model Struktur elemen-elemen dalem

\section{KESIMPULAN}

Sebagai kesimpulan dari penelitian ini dapat disampaikan bahwa: pertama ruang publik merupakan bagian integral dari upaya masyarakat Jawa mencari keselamatan hidup, khususnya dalam membangun relasi dan menjaga keselarasan dengan lingkungan masyarakat. Kedua, penggunaan pendekatan strukturalisme dalam penelitian ini terbukti mampu mengungkap struktur dalam yang tidak lain merupakan pikiran bawah sadar. Pendekatan ini dapat dimanfaatkan untuk membaca karya arsitektur lainnya. Ketiga, pemahaman atas ruang publik pada rumah tradisional Jawa memberi masukan kepada seluruh pemangku kepentingan yang terkait dengan perancangan ruang publik yang memperhatikan nilai-nilai lokal, misalnya dalam perancangan rumah publik pada rumah susun. Akhirnya, pemahaman baru atas ruang publik yang berlandaskan nilai-nilai lokal dapat menjadi rujukan sekaligus alternatif rancangan ruang publik yang sejajar dengan rancanganrancangan ruang publik yang berorientasi pada nilai-nilai asing.

\section{REFERENSI}

[1] Carr, Stephen, et.al.(1992). $\underline{\text { Public }}$ Space. [22-25]

[2] Madanipour.(2003). Public and Private Spaces of the City. [01-04].

[3] Nasbitt, John.(1995). Global Paradox. The Bigger the world Economy, the More Powerful its Smllest Players.

[4] Ahimsa-Putra, Heddy Shri.(2006). Strukturalisme Levi-Strauss Mitos dan Karya Sastra.

[5] Capon, David Smith.(1999). Architectural Theory Volume 1 and 2.

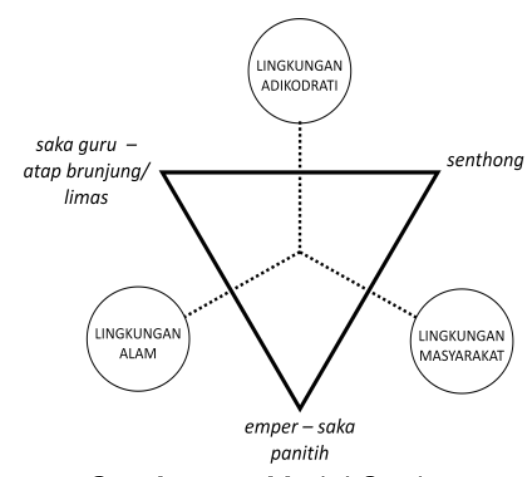

Gambar 14. Model Struktur Elemen-eleman upacara daur hidup

[6] Salura, Purnama andFauzy, Bachtiar.(2012) The Ever-rotating Aspects of Function-Form-Meaning in Architecture. Journal of Basic and Applied Scientific Research. ISSN 2090-4304.

[7] Adrisijanti, Inajati. (2000). Arkeologi Perkotaan Mataram Islam.

[8] Magnis-Suseno, Franz.(1984). Etika Jawa: Sebuah Analisa Falsafi tentang Kebijaksanaan Hidup Jawa.

[9] Ahimza-Putra, Heddy Shri.(2002). Tari "Srimpi" dan Struktur Simbolisme Jawa. Makalah Seminar Harapan Seni Pertunjukan dalam Masa Globalisasi dan Desentralisasi. 
